\title{
An Existential Crutch?: Interrogating Women's Silence in Select Plays of Mahesh Dattani
}

\author{
Manisha Sinha \\ Ph.D. Research Scholar, Amity Institute of English Studies and Research, Amity University, \\ Noida. ORCID ID: oooo-0oo1-9205-533X. Email:manisha.s27@icloud.com
}

\begin{abstract}
Silence can stem from myriad stimuli, including but not limited to quietude, speechlessness, secretiveness or repression. The oppressed and marginalised women often resort to the 'act' of silence to survive in a patriarchal society. Indian playwright Mahesh Dattani has raised the social problem of misogyny in several of his plays. The women in these plays are neither timid nor shy. Yet, despite being quite vocal about various aspects, they keep parts of their lives buried in deep secrecy. Their selective silence also raises pertinent questions regarding gender-based power equations. Exploring the interconnection between patriarchy and silence in Mahesh Dattani's Where Did I Leave My Purdah? and Final Solutions, this paper attempts to analyse as to whether silence of women in these plays is a manifestation of their agency or indirect patriarchal imposition.
\end{abstract}

Keywords: feminism, patriarchy, silence, partition literature, Indian drama.

\section{Introduction}

So some speak and others are silent.

(Luce Irigaray, Speculum of the Other Woman (1985, p. 257)

Silence is a complex psychic state of refraining from speaking about something or answering questions (Zeligs 1961; CUP). This "potentially powerful human experience" (Valle 2019, p.219) can signify anger, fear, displeasure, sadness, speechlessness, secretiveness or repression. The act of silence is usually associated with victimization or disempowerment, but that may not always be the case (Mahoney 1996, p.603). While Irigaray reclaims silence as a force of regeneration (Godart, 2016, p.19), Mahoney (1996) sees it as a possible "avenue of power" (p.6o3), Godart (2016) states:

Patriarchy consistently deploys silence as a weapon against women... Yet silence can be productive: from the fissures it makes into the raucous world, new thoughts, aspirations, and desires can emerge. (p.9)

A tactful silence has the potential to avert articulating apparently "inappropriate" feelings and thoughts (Zeligs 1961). The oppressed and marginalised women may resort to silence to survive in a patriarchal society, utilising it as a site of strength and resistance (Valle 2019). Indian playwright Mahesh Dattani's plays Final Solutions (1993) and Where Did I Leave My Purdah? (2012) present

(C) AesthetixMS 2020. This Open Access article is published under a Creative Commons Attribution Non-Commercial 4.0 International License (http://creativecommons.org/licenses/by-nc/4.0/), which permits non-commercial re-use, distribution, and reproduction in any medium, provided the original work is properly cited. For citation use the DOI. For commercial re-use, please contact editor@rupkatha.com. 
complex women characters whose silent sufferings raise questions on the existence/lack of their own agency and the role of patriarchy. These women are strong and anti-patriarchal characters who take judicious decisions. The research question is as to whether their judiciousness is influenced by patriarchal rules of the time or it is an attestation of their agency. This paper hypothesizes that either directly or obliquely, patriarchy is the reason behind the selective silence of women in both these plays.

\section{'Silence' in Selected Drama}

Final Solutions, as Alyque Padamsee notes, is about "transferred resentments" and "simmering undercurrents" of prejudices (Collected Plays, 2000, p. 161). Though its predominant theme is the vicious circle of communal hatred, the concurrent theme of gender discrimination depicts female subjugation in the Indian society. The play is set in the backdrop of Hindu-Muslim riots, one in 1948 after the India-Pakistan partition, and another, decades later in Gujarat. The first Act opens with Daksha, a fifteen-year-old girl, penning her first diary entry on $31^{\text {st }}$ March 1948 . Her monologue reveals that she got married when she was only fourteen years of age, and now that she is in her in-laws' house, she is forced to live according to their wishes. They even change her name from Daksha to Hardika "to match with Hari," her husband's name (C.P., 200o, p.174). A name not only symbolizes the personal identity of a human being but is also the primary marker of recognition for their specification (Meadow 1977, p.237). Research has established a close sociopsychological connection among an individual's name, their sense of identity and self-perception (Dion 1983; Sherif and Cantril 1947). Meadow states that the shortening or twisting of one's original name by another person "captures the symbolic essence of the relationship between two persons" (1977, p.237). In Daksha's case, her name is neither shortened nor altered partially. It is replaced by another name altogether. Nobody even thinks of asking for her consent in this matter, which means that her opinion is insignificant to all of them. She has no agency to change or forbid her in-laws from changing her name. She cannot even express her displeasure at their decision.

Although Daksha does not accept her name change inwardly, she chooses to remain silent instead of speaking against the deletion of her individual identity. Her silence on her name change depicts her helplessness in the matter, coupled with her need to adhere to the rules set by her husband's family to survive there. That Hari does not need to change his name or surname for his wife, and that his family imposes its decision on her, shows the hierarchal status of men and women in a patriarchal society. Daksha, however, refuses to address herself as Hardika in her private life. Her decision to retain her original name in her diary demonstrates her feminist streak. Traditionally, the husband is not treated on an equal footing with his wife but elevated to the ranks of her lord and master (Agnes 2007; Pennington 2001, p.590). Daksha thinks that Hari, whom she is required to treat as her "lord and master", is lazy and brainless (C.P., 2000. p.196). But she knows that as a married girl, she cannot be vocal about her thoughts and preferences. Jassal (2012) states that women "sing what they often cannot talk about". Daksha, who wants to become a singer like Noor Jehan, realizes that her wish can never be fulfilled because her in-laws would not allow her to pursue her passion of singing. Again, her agency, rather lack of it, comes into question.

For long, women's rights and issues were brushed under the carpet until the waves of feminism brought them under spotlight. Internalization of misogyny by women is also not uncommon in a patriarchal society. Daksha also thinks that it is not right for her to dwell over her 
sadness when there "more important things." She dismisses the significance of her personal experiences, thinking that she is "just a young girl who does not matter to anyone outside her home" (C.P. 166). The trivialization of gender discrimination and the belittling of women's attempt to bring their gender-related problems on public platforms have been called out by feminist scholars. The "personal is political" slogan was raised in the 196o's to highlight the link between women's personal experiences and their position within a system of gender-based power relationships (Hanisch 1970; Kelly 2017).

Daksha also realizes that Hari and his parents have been keeping some secret from her. It is evident that they do not trust her enough to share family secrets with her. In a way, she is kept isolated from the rest of the family. She is also subjected to verbal abuse by her husband when she asks about the matter. At this stage, it becomes obvious that they demand silence from her. She is not allowed to ask questions. She is not even allowed to eat with their Muslim neighbours. On mere suspicion that she may have eaten with them, her husband assaults her physically. Domestic violence against women is a criminal act, yet many culprits do not get punished by law partially because not many battered wives dare to file a legal complaint against their husbands. Research shows that domestic violence is associated with poor physical and mental health (Kalokhe, et al. 2017). According to a survey report published by National Family Health Survey (NHFS-4) in December 2017, every third ever-married woman has experienced spousal violence. It is noteworthy that only 14 per cent of women who have experienced physical or sexual violence have sought help to save themselves (p.563).

Even after being beaten badly by her husband, Daksha continues to live with him, bearing the oppression silently. She is never allowed to go out of the house. She chooses silence over rebellion. Stressing on the limitedness of individual struggle, Carol Hanisch (2006) states, "Women are sometimes smart not to struggle alone when they can't win and the repercussions are worse than the oppression" (p.3). 'Win' and 'repercussions' are noteworthy words in this context. If they are sure to lose their fight against patriarchy, they prefer not to go to war. Now, is this preference or their 'smart' decision a testimonial to their agency? Do they really have a choice? On the surface level, it appears that they do have the options of either bearing the oppression silently or to speak against it, and Daksha chooses the former. But, had she opted for the latter, she might have been thrown out of the house, and in all probability, shamed and shunned by society too, due to the draconian patriarchal social structure at that time. So, basically, she has no plausible choice. Her decision is made on the foundation of patriarchal rules.

Forty years later, Daksha contemplates that "things have not changed that much" (C.P., p.167). Communal tensions are still prevalent, and so are gender-based issues. When Daksha's daughter-in-law Aruna comes to know that her daughter, Smita, has acquaintance with boysMuslim boys, Aruna remarks, "Stop her studies! From now on, she can stay at home!" (p.188). It seems that history is about to repeat himself. Daksha was confined inside the house forty years ago, and now her granddaughter faces the same threat. It was in 1792 that Mary Wollstonecraft took up the case of women's education and emancipation. Centuries later, the education of females is still considered secondary to that of males. Their education is constantly under threat. It is a common perception in extremely patriarchal families and communities that education might corrupt girls. As depicted in this play, the female population is expected to bear atrocities with silence, since their very existence depends on it, as seen in the case of Daksha.

Dattani's other play, Where Did I Leave My Purdah? is also set against the backstory of Hindu-Muslim riots. The protagonist, Nazia Sahiba, is initially presented as an idiosyncratic and manipulative old woman. Ruby, who calls Nazia her aunt, claims that the latter usurped the credit 
that should have gone to Ruby's mother and Nazia's sister Zarine. Nazia asserts that she started the Modern Indian Theatre sixty-five years ago, but upon Ruby's intervention, revises her statement, saying that she, "along with a few others" started the historic theatre company (MMP, 2014, p.62). Ruby accuses Nazia of being an extremely selfish woman and a liar. Little does she know that Nazia has been hiding a life-changing secret from everyone. Behind Nazia's spirited and quirky demeanour is an inner turmoil, a history of trauma that she chose to bury in her past. In 1948, when India and Pakistan are reeling from Hindu-Muslim riots and violence, Nazia, her lover Suhel, and her sister Zarine work together in Lahore in the theatrical production of Shakuntala, a dance drama in Hindustani. To shift to Delhi, they board a train that witnesses a massacre of Hindu passengers by Muslim fanatics near the border. Nazia recounts, "The rioters wanted to kill everyone on the train. A train full of Hindus. Except for us. The woman next to us told us to wear our burqas. That would save us ...” (p.128).

Suhel wears a cap while Zarine takes out her burqa. But Nazia is unable to find her burqa. Zarine surreptitiously puts her burqa in Nazia's trunk. Nazia wears it and wonders why Zarine has not worn hers. By the time she realises her sister's sacrifice, it is too late. Without her burqa, Zarine is mistaken as a Hindu and is attacked by the people of her own religious community. Suhel drags away Nazia, who is shocked to see the "butchers" on her sister Zarine (p.13o). When Suhel and Nazia enter India, they encounter "a different set of demons" (p.13o). Hindu fanatics attack burqa-clad Nazia and gangrape her.

Later, the train from Pakistan, laden with dead bodies of Hindu passengers, reaches India. Suhel recognises Zarine's dead body on seeing her ring and show the hand to Nazia. Traumatised by her own gangrape and her sister's brutal murder, Nazia somehow manages to prepare a respectable shroud for Zarine by covering her in that burqa. Since then, she never wears burqa ever again, not does she speak about her rape. But Nazia's trauma does not end at that. She becomes pregnant as a result of the gangrape. Despite getting married to Suhel, she knows that she cannot hide the fact from him. When her child is born, Nazia does not want to look at the baby, as the latter's existence keeps reminding her of the trauma. So, she decides to keep a distance between herself and her baby. Her gangrape, coupled with Suhel's passivity and inaction at that moment, causes an irreparable rift between them as well. Rape narratives have often been treated as taboos, and rape survivors as defiled and degraded, in patriarchal societies. Nazia has little choice but to bury her traumatic past quietly and move on in her life as a strong woman. She tells everyone that Ruby is the child of her now-deceased sister, Zarine. Her only connection to the past is Suhel, her ex-husband, with whom she is not in touch anymore.

For decades, Nazia deploys silence as an existential strategy to survive the violation of her body and the subsequent trauma, and to live 'respectfully'. She exhibits a rebellious streak, yet she decides to keep her past hidden from everyone. Even when Ruby, her own daughter, repeatedly taunts and asks her questions regarding her past, Nazia tries to deflect the questions and appear unperturbed. Speaking of her existential tool of silence, Nazia accepts that despite knowing the facts "deep inside," one does not want to acknowledge the truth in the hope of erasing it, but that is not possible.

Nazia: We all weave these tangled webs around the truth so we can strangle it and make it disappear. We are all deceiving one another. (MMP, p.126)

A pertinent question arises as to whether she has been 'deceiving' only others or herself too. Nazia is portrayed a "feisty, passionate and self-absorbed diva" (Dubey, 48) who likes to live life to the fullest. She not only plays practical jokes on unsuspecting people but also dares to speak up against those in authoritative position. But when it comes to the authority of patriarchy, 
she is forced to submit to its unwritten law that relegates a woman from mainstream society to its margins if she is a rape-survivor. Apart from trauma from rape and post-traumatic stress, patriarchal stigma attached to sexual assault plays a humungous role in her resolution to keep her past under wraps. She is able to lead a respectable public life because she chooses to play by patriarchal rules. Her silence, however, adversely affects her next two generations. Both Ruby and her daughter Nikhat become a victim of their circumstances. Referring to the chain of silent sufferings, Mrunal Chavda states, "Nazia is angry due to Suhel's passivity during her rape whereas Ruby is annoyed because her mother had abandoned her. Similarly, Ruby's daughter, Nikhat is angry with her mother and wants recognition from her mother" (Chavda 2020).

Nazia maintains a stoic silence until she sees her granddaughter Nikhat, who is her spitting image. Just as King Dushyant remembers his past on seeing Shakuntala's ring, on seeing Nikhat, Nazia breaks her silence on her traumatic experiences and speaks for the first time about the horrors she had faced after the partition as a young Muslim woman. It is worth noting that she speaks in the twenty-first century, when patriarchal structure is not as dominant and easily acceptable as in the twentieth century in India, and rape is not that strongly associated with dishonour in current times. According to the blurb for Culture and Agency (1996), "People inescapably are shaped by the culture in which they live, while culture itself is made and remade by people" (Archer, 1996). The progressive change in cultural dynamics gives Nazia, presently in her eighties, greater individual capacity to axe those "tangled webs" (MMP, p.126). So, both her choices- to maintain silence earlier and to break it later- are influenced circuitously by the social structure of patriarchy.

\section{Conclusion}

In both plays, Dattani has depicted the use of silence by women who are bound by societal rules of honour and modesty. Patriarchy imposes silence upon women by rewarding them with tags of being morally upright, obedient, worthy, honourable etc. However, women who do not subscribe to patriarchal ideology may utilise silence as a defence mechanism and use it as a tool to navigate through the rough patches of their lives. As Zeligs (1961) points out, silence can be a voluntary gesture as well "an unconscious protective process against any kind of threat" (10). This is aptly shown in these plays through the characterisation of Daksha and Nazia. They choose silence to live with 'honour' in the patriarchal society they exist in. They safeguard their space by hiding their 'truths', thereby dodging direct (and possibly harsher) patriarchal impositions, such as being outcast by society. But, since the reasons of their silence are firmly rooted in patriarchy, they decisions cannot be said to be independent of its influence. Their strategic silence is not a manifestation of their agency, but rather of their survival instinct and will power to pull through. Both these plays expose the detrimental effects of the patriarchal social structure on the female population. Referring to the gendered violence at the time of India-Pakistan partition, Khanna (2014) states, "The stronger force of patriarchy stifled their voices and denied them any agency to speak up and to narrate their traumatic past" (19). For these women, silence becomes the crutch they need to keep body and soul together. It is the support system they develop to help themselves survive with 'respect' in a misogynistic society. 


\section{References}

Cambridge Dictionary. (n.d.) Silence. In Dictionary.cambridge.org. Cambridge University Press (CUP). Retrieved July 10, 2020, from https://dictionary.cambridge.org/dictionary/english/silence

Agnes, F. (2007). Nation Building through the Enactment of Hindu Code Bill — The Nehruvian Agenda. Contemporary Perspectives, 1(1), 67-85. https://doi.org/10.1177/223080750700100106

Archer, M. S. (1996). Culture and Agency: The Place of Culture in Social Theory (2nd ed.). Cambridge: Cambridge University Press. http://doi.org/10.1017/CBO9780511557668

Brian K. Pennington (2001). Constructing Colonial Dharma: A Chronicle of Emergent Hinduism, 18301831, Journal of the American Academy of Religion, Volume 69, Issue 3, Pages 577604, https://doi.org/10.1093/jaarel/69.3.577

Cathy Caruth (2001). Parting words: Trauma, silence and survival, Cultural Values, 5:1, 726, DOI: $10.1080 / 14797580109367218$

Chavda, Mrunal (2020). The Natyashastra-based analysis of Mahesh Dattani’s Where Did I Leave My Purdah. Rupkatha Journal on Interdisciplinary Studies in Humanities. Vol.12. No.1. 1-13. https://dx.doi.org/10.21659/rupkatha.v12n2.09

Dattani, M. (2000). Final Solutions. In Collected Plays (C.P.) New Delhi: Penguin Books.

Dattani, M. (2014). Where Did I Leave My Purdah? In Me and My Plays (MMP). Penguin Books Ltd. Kindle Edition.

Caroline Godart. (2016). Silence and Sexual Difference: Reading Silence in Luce Irigaray. DiGeSt. Journal of Diversity and Gender Studies, 3(2), 9-22. doi:10.11116/jdivegendstud.3.2.00o9

Irigaray, L. (1985). Speculum of the Other Woman. p. 257. Cornell University Press.

Kenneth L. Dion (1983). Names, Identity, and Self, Names, 31:4, 245-257, DOI: 10.1179/nam.1983.31.4.245

Caroline Godart. (2016). Silence and Sexual Difference: Reading Silence in Luce Irigaray. DiGeSt. Journal of Diversity and Gender Studies, 3(2), 9-22. doi:10.11116/jdivegendstud.3.2.00o9

Hanisch, Carol. (2006). The Personal is Political. Introduction. https://webhome.cs.uvic.ca/ mserra/AttachedFiles/PersonalPolitical.pdf

Jassal, S. T. (2012). Unearthing gender: folksongs of North India. Duke University Press.

Kalokhe, A., Del Rio, C., Dunkle, K., Stephenson, R., Metheny, N., Paranjape, A., \& Sahay, S. (2017). Domestic violence against women in India: A systematic review of a decade of quantitative studies. Global public health, 12(4), 498-513. https://doi.org/10.1080/17441692.2015.1119293

Kelly, C.J. (2017). The Personal is Political. Encyclopeedia Britannica, Inc. https://www.britannica.com/topic/the-personal-is-political

Khanna, Tanvi. (2014). Silence, Survival and Recuperation: Reading Women's Literature. RJELAL. Vol. 2 Issue 3. http://www.rjelal.com/2.\%203.2014/Tanvi\%2019-25.pdf

Kjerstin Almqvist \& Anders G. Broberg. (1997). Silence and survival: Working with strategies of denial in families of traumatized pre-school children, Journal of Child Psychotherapy, 23:3, 417435, DOI: 10.1080/0075417970825456o

Mahoney, M. (1996). The Problem of Silence in Feminist Psychology. Feminist Studies, 22(3), 603-625. doi:10.2307/3178132

Meadow, K. (1977). Name Signs as Identity Symbols in the Deaf Community. Sign Language Studies, (16), 237-246. Retrieved August 19, 2020, from www.jstor.org/stable/26203239 
National Family Health Survey (NFHS-4). (2017). International Institute for Population Sciences (IIPS) and ICF, India. 2015-16. http://rchiips.org/nfhs/NFHS-4Reports/India.pdf

Padamsee, A. (2000). A Note on the Play. In Collected Plays. New Delhi: Penguin Books.

Sherif, M., \& Cantril, H. (1947). The psychology of ego-involvements: Social attitudes and identifications. New York: John Wiley \& Sons, Inc.

Valle, R. (2019). Toward a psychology of silence. The Humanistic Psychologist, 47(3), 219261. https://doi.org/10.1037/humoooo120

Wollstonecraft, M. (1992). A Vindication of the Rights of Woman. 1792. The Works of Mary Wollstonecraft, 5, 217.

Zeligs, M. A. (1961). The Psychology of Silence: Its Role in Transference, Countertransference and the Psychoanalytic Process. Journal of the American Psychoanalytic Association, 9(1), 743. https://doi.org/10.1177/000306516100900102

Manisha Sinha is a doctoral research scholar at Amity Institute of English Studies and Research (AIESR), Amity University (Noida), India. Her research areas are Indian English literature and Gender Studies. Her other areas of interest are cultural studies and creative writing. She has qualified the National Eligibility Test (NET) for Assistant Professorship in English as well as in Women's Studies. She has presented several research papers at seminars and conferences in India and abroad. Prior to academic research, she worked as a journalist in New Delhi. 